\title{
NOTES ON SOME SPECIES OF PISIDIUM.
}

\author{
By B. B. Woodward, F.L.S.
}

Read 13th May, 1921.

Pisidium cinereum, Alder, vice P. casertanum, Poli.

When the "Catalogue of the British Species of Pisidium" was issued in 1913, Poli's work ${ }^{1}$ being binominal was accepted by most zoologists, and had been included in Sherborn's "Index Animalium ". Since there was no doubt as to the identity of his Cardium casertanum, which, moreover, was the sole species in the type locality, and the name had been in use on the Continent, it was adopted in the "Catalogue." The fact, however, that Poli consistently gave in each case one name to the shell and another to the contained animal has since led to his book being ruled out as not a serious contribution to systematic zoology, and his names have to be discarded.

What, then, will be the best name to replace casertanum, because of those included in its synonymy some may, nevertheless, be open to question when absolute certainty of identification is demanded.

The next in order of date is the Cyclas vitrea of Risso, ${ }^{2}$ of which the description is inadequate. Comm. E. Caziot most kindly sent me plesiotypes of the specimens that are now in Risso's old collection under the name, and these were certainly casertanum. There is, however, grave doubt whether, considering the vicissitudes the collection has been through, ${ }^{3}$ the present are the original specimens ; certainly the name does not favour it. Risso could hardly have described these shells as glassy. Hence it does not seem advisable to accept his name.

The Cyclas prisca of Eichwald, ${ }^{4}$ which follows, was founded for a fossil from a freshwater deposit at Kuncza, Podolia. The description is worthless, and although Eichwald's figure ${ }^{5}$ suggests the present, or some closely allied species, until the type is known its exact nature is uncertain, and the name best passed by.

Of the Pisidium australe of Philippi, ${ }^{6}$ it can be stated that while the description is better, it is still too general for purposes of exact identification and the figure is poor and quite unidentifiable.

\footnotetext{
1 Testacea utriusque Siciliæ, etc.

2 Hist. Nat. Europ. mérid., iv, 1826, p. 338.

3 Proc. Acad. Nat. Sci. Philad., 1919, p. 157.

4 Naturh. Skizze Lithauen, 1830, p. 207 ; and Lethæa Rossica, iii, 1852, p. 87 , pl. $v$, f. 8 .

5 The figure given in illustration of this species by Hoernes, "Foss. Moll. Tertiär-Beck. Wien," Abhandl. k.k. Geol. Reichsanst., iv, 1870, pl. xx, f. 1, and repeated by Sandberger, "Land- and Süssw.-Conch. Vorwelt," 1875, pl. $\mathrm{xxx}, \mathrm{f} .6$, is quite a different shell.

6 Enum. Moll. Sicil., i, 1836, p. 39, pl. xiv, f. 11.
} 
Specimens received from the Continent under this name are mostly flattened forms of casertanum, which is hardly consonant with the "tumidiuscula" of Philippi's description. In the absence of the type, and considering the doubt attaching to its identification, it will be wiser, for the present at all events, not to adopt the name.

As regards the Pisidium cinereum of Alder, ${ }^{7}$ we are furnished with a description, which, though far ampler than those of the species just passed in review, still leaves much to be desired for the purposes of modern requirements. On the other hand, Alder's types are extant in the Newcastle Museum, and from these and the numerous co-types distributed by him to correspondents, the identity of his species is well established, so that we are on sure ground, and hence it would be safest in my judgment to employ his name in future for the species.

\section{Pisidium parvulum (Clessin MS.) Westerlund.}

This species was established by Westerlund on Clessin's manuscript in $1873,{ }^{8}$ with a very imperfect description, and no figure. . A variety, martensi, Cl., was also indicated. The habitat being given as Blekinge district, near Ronneby. The species was repeated by Clessin in his monograph on the "Cycladeen" and figured."

Whilst preparing the "Catalogue of the British Species of Pisidium ", I received from Dr. A. C. Johansen examples of a Danish form under the above name, and, although it had not then been found in Britain, included it, with illustrations, in the "Catalogue" as a species to be looked for, but did not so completely describe it as I should have done had it been British. The occurrence of the same form in Lake Baikal was also noted, whence it had been received under the name " $P$. aliena, Mts."-a name which cannot be traced, and which has certainly nothing to do with the $P$. alienum of Clessin, ${ }^{10}$ which is a synonym for $P$. amnicum, var. nova, Paul.

In 1914 Dr. Johansen in a "Note on the Danish species of Pisidium ", pointed out that this Danish form was apparently not the parvulum, Clessin, of Westerlund, but distinct. He further mentioned that some co-types from Ronneby, determined by Westerlund, belonged to $P$. obtusale.

For reasons which will presently become apparent, it seemed desirable to probe this question now, and accordingly endeavours were made to see or ascertain the identity of authenticated specimens. Dr. Scharff of the National Museum of Ireland very kindly allowed me to inspect specimens under his charge that comprised two sets from Ronneby, the one received directly, the other indirectly from

7 Trans. Nat. Hist. Soc. Northumberland, ii, 1838, p. 341.

8 Fauna Moll. Sveciæ, ii, p. 553.

9 Syst. Conch.-Cab., ed. Küster, 1874, p. 17, pl. i, f. 17-21.

10 Ib., p. 269, 1879.

11 Vidensk. Meddel. Dansk. Naturh. Foren., lxvi, pp. 81-3. 
Dr. Westerlund. The former set, labelled by Westerlund himself, proved to consist of two opened and one closed pair of $P$. pusillum, and two opened pairs of $P$. hibernicum. The second set included two valves of $P$. cinereum, f. lacustris, and four valves of immature $P$. pusillum.

Dr. Nils $\mathrm{Hj}$. Odhner most obligingly sent for my inspection from the Stockholm Museum a tube labelled in Clessin's handwriting "Pis. parvulum Cless | Bleckinge | 1gt Westerlund | com. Clessin". This gathering included two whole $P$. milium, one whole $P$. nitidum, and five valves of $P$. hibernicum. Dr. Odhner informed me that he had received from Berlin one of the original specimens of the variety which proved to be $P$. obtusale.

Dr. D. Geyer of Stuttgart has been so good as to examine Clessin's collection there. He reports finding three gatherings of $P$. parvulum, which on inspection resolved into: small obtusale, half-grown nitidum, young cinereum, and three specimens of millum!

It is therefore quite obvious that Pisidium parvulum of Clessin and Westerlund is a composite of species all otherwise named and that the name must disappear from literature. The form, therefore, which of late has passed with us under that name, will take Stelfox's happily suggested designation, and be known as :-

\section{Pisidium torquatum, Stelfox.}

When this species was first added to the British fauna in 1916 by Mr. R. A. Phillips, ${ }^{12}$ the only standard of comparison which we possessed were the squarrose examples Dr. Johansen had sent me from Fursoe, and I was unable to assent to the reference of the whole of the specimens claimed as " parvulum" to that species and maintained that some, and especially the very triangular forms from the Thames Valley deposits, were merely the fry of $P$. supinum. ${ }^{13}$

Lately fresh fossil material has come into my hands and I have had the privilege of studying Mr. C. Oldham's collection of this form, and have verified the fact that examples quite as triangular as those in the Thames Valley deposits occur living at Welshpool. Whilst as to the distinction between torquatum and juvenile supinum, both Dr. Johansen in $1914^{11}$ and Mr. Stelfox in his useful paper on "The Pisidium Fauna of the Grand Junction Canal ", ${ }^{14}$ point out that there is a difference in the appendiculæ in the two forms. Strictly speaking they are not so much appendiculæ present in torquatum as a discontinuous junction between the nepionic and adolescent shell, somewhat similar to that in Sphorium lacustre, resulting in crescentic ridges conformable to the "lines of growth"; whereas in supinum and henslowanum the shelly ridges, which are sometimes quite sharp, usually cut obliquely across the "lines

12 Irish Naturalist, $\mathrm{xxv}$, p. 101.

13 Ann. \& Mag. Nat. Hist., ser. virI, vol. xviii, 1916, p. 346.

14 Journ. of Conch., xv, 1918, p. 299. 
of growth ", and may at times be exceedingly reduced or altogether wanting. It would be extremely interesting to know what modification of the mantle margin of the animal it is that gives rise to the formation of these appendiculæ at this stage of its growth, and, further, what possible purpose, if any, they serve.

Mr. Stelfox further points out a more subtile but equally important distinction, viz. that in torquatum the lateral teeth, p. i and p. iii, converge, whereas in supinum they remain parallel. Tested by these criteria it becomes evident that Mr. Phillips and Mr. Stelfox were right in their conclusions, and that my too great caution was not justified.

The bibliographic synonymy of torquatum is, therefore, as follows : 1898. Pisitium parvulum, Clessin : Johansen, Vidensk. Meddel. Dansk. Naturh. Foren., lxvi, pp. 152, 159, 160. [Non Clessin.]

1913. " " Woodward, Cat. Brit. Pisidium, p. 105, pls. ii, f. 6 ; iv, f. 8 ; xxvii, f. $3-6$. " supinum, A. Schum. [pars]: ib. pl. xv, f. $9 a-f$, $15 a-f, \quad 17 a-f ;$ xxvi, f. $3 a-f .12 a, b$; xxvii, f. $1 a-f, j-o$.

1918. " henslowanum, Shepp. [pars]: ib. pl. xxvi, f. $13 a, b$.
", torquatum, n.nov.: Stelfox, Journ of Conch., xv, p. 299, pl. viii, f. 14-21.

Dr. Geyer writes that the species does occur in Clessin's collection mixed with three or four others under the name of $P$. rivulare, from Anrieder Bach, near Dinkelscherben, Bavaria. He has also lately sent me specimens coming from the River Neckar, at Altbach, near Stuttgart, and reports having it also from the Rhine near Rotterdam, and at Mannheim, as well as from the Bodensee, near Friedrichshafen. Whilst there are specimens from Bohemia in the Clessin Collection.

The list of occurrences so far as at present known is :-

RECENT.

ENGLAND.

Bedfordshire.-BD.

R. Ouse, Bromham [C. O.].

Berkshire.-BK.

R. Thames, Streatley [C. O.].

Buckinghamshire.-BX.

Grand Junction Canal, Cheddington [C. 0.].

Cheshire-- $\mathrm{CH}$.

$\Rightarrow \quad$ " $\quad$ " $\quad$ R. Ouse, Newport Pagnell [C. O.].

Canal, Beeston Castle [C.O.].

Herefordshire.-HF.

R. Wye, Goodrich [C. 0.]. 
Hertfordshire.-HT.

Grand Junction Canal, Berkhampsted [C. O.].

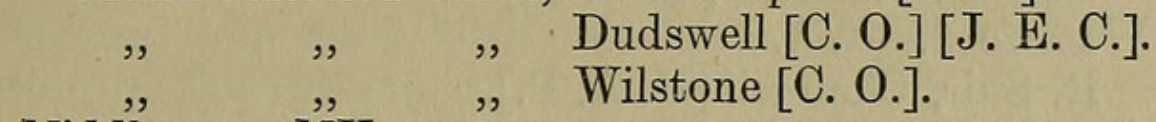

Middlesex.-M̈X.

R. Thames, Twickenham [C. O.] [J. E. C.].

Northamptonshire.-NO.

Canal, Rothersthorpe [C. O.].

Grand Junction Canal, Stoke Bruerne [C. O.]. Oxfordshire.-OX.

R. Thames, Streatley [C. O.].

Surrey.-SR.

Runney Mead [J. E. C.].

Wiltshire.-NW. and SW.

Canal, Seend [C. O.].

Worcestershire.-WO.

R. Severn, Stourport [C. 0.].

WALES.

Worcester [C. 0.].

Montgomeryshire.-MG.

IRELAND.

Canal, Welshpool [C. O.].

Antrim.-AN.

Canal, near Moira [C. 0.].

Galway, South.-SG.

R. Suck, Ballinasloe [C. O.].

HOLOCENE.

ENGLAND.

Bedfordshire.-B.D

Bromham [C. O.] [K. \& W.].

Hertfordshire.-HT.

Watford [C. O.].

Oxfordshire.-OX.

Clifton Hampden [K. \& W.].

Surrey.-SR.

IRELAND.

Near Staines [K. \& W.].

Carlow.-CW.

R. Barrow, Graiguenamanagh [R. A. P.].

Clare.-CL.

R. Shannon, Plassy, near Limerick [R. A. P.] [K. \& W.]. Kilkenny.-KK.

R. Barrow, New Ross [R. A. P.] [C. O.] [K. \& W.]. Graiguenamanagh [R. A. P.].

?" Fiddown [R.A.P.] [C. O.] [K. \& W.].

Limerick.-L.K

R. Shannon, Plassy, near Limerick [R. A. P.] [K. \& W.]. 
Tipperary, South.-ST.

R. Suir, Clonmell [R. A. P.].

Waterford.-WA.

R. Suir, Clonmell [R. A. P.].

Wexford.-WX.

Fiddown [R. A. P.] [C. O.] [K. \& W.].

R. Barrow, New Ross [R. A. P.] [C. O.] [K. \& W.].

PLEISTOCENE.

ENGLAND.

Cambridgeshire.-CB.

Barnwell [K. \& W.].

Essex, North.-NE.

Clacton [K. \& W.].

Essex, South.-SE.

Grays [C. 0.] [K. \& W.].

Kent, West.-WK.

Crayford-Erith [C. O.] [K. \& W.].

\section{CROMERIAN.}

ENGLAND.

Kent, West.-WK.

Swanscombe [K. \& W.].

Norfolk, East.-EN.

Mundesley [K. \& W.].

Sidestrand [K. \& W.].

The initials in [ ] are those of the several collectors who hold specimens, viz. : C. Oldham, J. E. Cooper, Kennard \& Woodward, and R. A. Phillips.

\section{Pisidium hibernicum, Westerlund.}

This proves to be a far more polymorphic species and far more widely distributed than was at first thought, as shown by Mr. Phillips and Mr. Stelfox in their important paper on it and its range. ${ }^{15}$

In the early days of one's study of the British Pisidia, whilst taking the forms from Lough Nagarriva, the type locality, as the standard, although recognizing they were probably abnormally inflated, one was unprepared for so wide a distribution and hence cautious about attributing to this species forms that might well be only varieties of other, better-known species. Decisions were then come to by me, which the authors of the above-named paper quote as final, that might have been modified had opportunity been courteously afforded for defence or recantation. In some instances it is even possible that the gatherings which were submitted to me from a given locality may not have contained representatives of the species at all, or only a few readily overlooked in the number. 
Opportunity having lately presented itself to carry out a longdeferred intention to reinvestigate the matter, I applied to Mr. Oldham, who most kindly lent me the whole of his valuable collection of the species, which is specially rich in examples from remote Welsh tarns. To him my thanks are due and hereby tendered, as well as to Mr. Cooper and Mr. Overton, for the chance of inspecting additional gatherings.

Studied thus in the bulk, a truer appreciation of the species as a whole is possible. The outstanding feature externally, in addition to its globular form, in which it comes nearest to $P$. obtusale, is the fact that the lines of growth are not only "regular, close, and well marked ${ }^{15}$ (p.36)", but that they are present on the nepionic shell. It differs in this respect from both $P$. nitidum and $P$. pusillum, in which the nepionic shell is usually smooth, followed by a band of strongly marked, deeply incised lines, a feature noted by Jenyns as characteristic of the former, but overlooked by him in the latter species. In $P$. hibernicum, moveover, there is a suggestion when viewed under the microscope, of faint radial sculpture rarely present in other species. Internally the chief feature is the short hinge-line, just as in $P$. obtusale, and, in fact, all orbicular bivalves. This shortness of the hinge-line persists in most of its form mutations, although if the determination and drawings be correct, it is somewhat departed from in the specimens from Gortymadden figured by Phillips and Stelfox ${ }^{15}$ (pl.i, f. 7 and 8). In addition the points of the lateral teeth, when viewed sideways, stand up more sharply, as shown in the "Catalogue" than they do in other species of the genus. Diagrammatically expressed they are $\Lambda \wedge$ rather than

A thorough examination was made of all the samples in the Kennard-Woodward collection, with the result that a few Irish representatives were detected as misplaced, namely : under obtusale, examples from Lough Acapple (Donegal); Tully Lough (Fermanagh); and Lough Nalackan, Brandon Mt. (Kerry); whilst a tube of " pusillum" from Lough Nafeola (Fermanagh) proved divisible into hibernicum and nitidum. An equally careful research in the collections at the British Museum (Natural History) yielded no instance of any misidentified hibernicum.

List of occurrences so far seen and determined by the writer :RECENT.

ENGLAND.

Bedfordshire.-BD.

R. Ouse, Bromham [C. O.].

Buckinghamshire.-BX.

R. Thames, Denham Lock [J. E. C.].

R. Colne, Iver [J. E. C.].

Wendover Canal, Halton [C. 0.].

Cambridgeshire.-CB.

R. Ouse, Ely [C. O.]. 
Cheshire.-CH.

Baguley Moor [C. O.].

Cumberland.-CU.

Dale Head Tarn $\left(1,600^{\prime}\right)$, Barrowdale [C. 0.].

Knott's Dock Tarn, Borrowdale [C. O.].

Barrow Bay, Derwentwater [C. O.].

Blea Tarn, Eskdale [C. O.].

Deroke Water, Eskdale [C. O.].

Friar's Crag, Derwentwater [C. 0.].

Gloucestershire, East.-GE.

Canal at Stroud [C. O.].

Hertfordshire.-HT.

Fishpond, Aldenham Abbey [C. 0.].

Brook at Cassio Bridge, Watford [C. O.].

Lancashire, Mid.-ML.

Haweswater, Silverdale [C. O.].

Lancashire, South.-SL.

Canal at Reddish [C. 0.].

Middlesex.-MX.

R. Colne, Harefield [J. E. C.].

Stanwell [J. E. C.].

Northamptonshire.-NO.

R. Nene, Northampton [C. O.].

Staffordshire.-ST.

Froghall [C. 0.].

Great Barr Park, near Walsall [H. O.].

Suffolk, West.-WS.

Fen drain, Lakenheath [C. 0.].

Surrey.-SR.

Chobham [C. O.].

Kew ditch [J. E. C.].

R. Wey, Woking [C. O.].

Warwickshire.-WW.

Sutton Coldfield district [H. O.].

Westmorland and Lake Lancashire.-WL.

Little Water, Bampton [C. O.].

R. Beetha, Beetham [C. 0.].

Brother's Water [C. O.].

Elterwater [C. 0.].

Esthwaite (217') [C. 0.].

Grasmere (204:') [C. 0.].

Hawes Water [C. O.].

Lingmoor Tarn $\left(1,300^{\prime}\right)$, Langdale [C. O.].

Little Langdale Tarn $\left(340^{\prime}\right)$ [C. O.].

Loughrigg Tarn [C. O.].

Reservoir at Patterdale [C. O.].

Nab Cottage, Rydal Water [C. O.]. 
West side of Rydal Water [C. O.].

Pull Wyke Bay, Windermere [C. O.].

Yorkshire, South-West.-WY.

WALES.

Marsden [C. O.].

Breconshire.-BR

Canal at Brecon [C. O.].

Carnarvonshire.-CR.

Llyn Anafon $\left(1,630^{\prime}\right)$ [C. 0.].

Llyn Diwaunedd $\left(1,208^{\prime}\right)$ [C. 0.].

Llyn Dwythweh (920'), Llanberis [C. O.].

Llyn Mymbyr (588'), Capel Curig [C. O.]

Llyn Ogwen (984') [C. O.].

Llyn Padarn (340') [C. O.].

Llyn Peris $\left(340^{\prime}\right)$ [C. O.].

Denbighshire-DB.

Llyn Aled (1,740') [C. 0.].

Glamorganshire.-GM.

Llandaff [C. 0.].

Merionethshire.-MN.

Fairbourne, Barmouth [C. O.]

Llyn Cyri (1,200'), Cader Idris [C. 0.].

Tarn on Y Garn $\left(1,800^{\prime}\right)$, Dolgelly [C. 0.].

Llyn Dulyn $\left(1,740^{\prime}\right)$, Llanddwywe [C. 0.].

Llyn Cwm Mynach (950') [C. O.].

Llyn Irddyn $\left(1,029^{\prime}\right)$ [C. 0.].

Ilyn Lliwbran (1,500') [C. O.].

Llyn Y Bi $\left(1,400^{\prime}\right)$ [C. O.].

Montgomeryshire.-MG.

Llyn Du Meiford [C. O.].

IRELAND.

Antrim.-AN.

Loughs $\left(1,000^{\prime}\right)$ west of Carnlough [K. \& W.].

Clare.-CL.

Lough Derg [C. O.].

Cork, West.-WC.

Lough Namaddra $\left(1,200^{\prime}\right)$ [C. O.] [K. \& W.].

Down.-DO.

Ballyholme [C. O.].

Donegal, East.-ED.

Lough Acapple [K. \& W.].

Fermanagh.-FE.

Awaddy Lough [K. \& W.].

Lough Nafeola [K. \& W.].

Tully Lough [K. \& W.].

Galway, West.-WG.

Lough Gowlanagower, Inishbofen [K. \& W.].

Lough Inch [J. E. C.] [K. \& W.]. 
Galway, South.-SG.

Lough Derg [C. 0.].

Lough Rea [C. O.].

Kerry, South.-SK.

Lough Nagarriva $\left(1,200^{\prime}\right)$ [J. E. C.] [K. \& W.].

Lough Nalackan $\left(1,150^{\prime}\right)[$ K. \& W.].

Tipperary, North.-NT.

Lough Derg [C. O.].

Waterford.-WA.

Lough Coumshingaun [C. 0.].

HOLOCENE.

ENGLAND.

Somersetshire, North.-NS.

IRELAND.

Burnham [K. \& W.].

Down.-DO.

White Bog, Killough [C. O.]. [K. \& W.].

The initials in [ ] are those of the several collectors who hold specimens, viz. : C. Oldham, J. E. Cooper, H. Overton, and Kennard and Woodward.

Pisidium steenbuchit, Möller.

To his paper on "The Pisidium Fauna of the Grand Junction Canal " 16 Mr. Stelfox appended notes on some species which had not been found in those waters. Among these (p. 301) was $P$. steenbuchii, of which he received for study a single example from Boveney, from Mr. J. E. Cooper, and he suggested that this species is nothing more than a "rather uncommon variety of $P$. nitidum". Since then a second specimen has been detected among some other Boveney shells and placed in the same box.

The original determination of this and other examples from widely different localities was made after careful comparison with co-types of steenbuchii kindly sent me from the Zoological Museum at Copenhagen, but it has seemed well under the circumstances to check this conclusion. Accordingly having been favoured once again by Mr. Cooper with the loan of his specimens, I have compared his and my own examples anew with the co-types of steenbuchii, and can find no reason for altering my former determination.

Of course, looked at carelessly they do superficially resemble nitidum, save that they are somewhat larger and differ in their sculpturing. The dentition, too, is fairly similar in both species, but there are persistent differences observable by the careful student, which separate them, and the more important of these were duly set forth in the text (to which Mr. Stelfox never seems to refer) of the "Catalogue of the British species of Pisidium", and need not here be elaborated over again. Mr. Stelfox invites a com-

${ }^{16}$ Journ. of Conch., xv, 1918, pp. 289-304. 
parison of his figures with the diagram on pl. ii of the "Catalogue", and vaunts the superiority of his method. This eulogy must surely have been penned ere the reproductions of his drawings had been received from the engraver, for if I was unlucky in having my excellent photographs spoilt as they were by bad collotyping, he has been still more unfortunate. Yet when the wrecks of his drawings are carefully examined by one acquainted with the two species it looks as if the draughtsman had detected and figured the differences in c. iii of the hinge.

Mr. Stelfox states that he has seen other examples of $P$. nitidum similar to the Boveney specimen from other localities. Is it possible that just as in the beginning I came to grief over $P$. hibernicum he has now missed the opportunity of extending our knowledge of the range of $P$. steenbuchii?

\section{ADDENDUM.}

\section{Read 10th June, 1921.}

REGRETTABLE though it be, the trivial names of two more species of Pisidium will have to be changed. Both $P$. pusillum and $P$. obtusale were taken by Jenyns at second and third hand from names given to species which prove indeterminate and consequently not available under our modern regulations as to nomenclature.

The following new names are consequently proposed :-

Pisidium pusillulum, nom. nov., vice $P$. pusillum, Jenyns (of B. B. Woodward), non Gmelin, nec Turton.

What the Tellina pusilla of Gmelin (Linn. Syst. Nat., ed. 13, i, pt. 6,1791, p. 3231 ) really was is not now ascertainable. The name was subsequently taken over by Turton in 1819 (Conch. Dict., p. 167) without reference to Gmelin, but in 1822 (Conch. Brit., p. 251, pl. xi, f. 16, 17) when changing the name to Cyclas pusilla he refers to Gmelin. Turton described the shell as "oblique tumid inequilateral", and evidently included all the smaller species of Pisidium under the designation. Nine years later, Turton (Manual, 1831 , p. 16 , f. 7 ) modified this to "obliquely suboval, convex". Jenyns, when he adopted the name from Turton in 1832 (Trans. Camb. Phil. Soc., iv, p. 302, pl. xx, f. 4-6), on the other hand, speaks of it as "Testa variabilis, plerumque orbiculato-ovalis, interdum suboblonga margine dorsali recto, vix inæquilateralis". Jenyns evidently in the three varieties distinguished by him included more than one form which would to-day rank apart. Of the " two extreme varieties" figured by him, one was probably the personatum of Malm, as suggested by me (Catalogue, p. 7), and subsequently by Mr. Oldham (Journ. Conch. xv, 1918, p. 237), who further found direct evidence on other tablets in the Jenyns collection of the presence of Malm's species under Jenyns' name. Since, however, Jenyns' name is inadmissible, all further discussion as to what constitited his species is unnecessary. 
The form to which, rightly or wrongly, I restricted the name pusillum of Jenyns, and which will have to take the new name, is a polymorphic one that seems to have puzzled malacologists, some of whom apparently regard it as an extreme form of nitidum. Truly it has much in common with that species; nevertheless, it appears to me to possess certain constant hinge characters, which justify its separation under a distinctive name. Its characteristics were duly set forth in the "Catalogue", p. 61, but the more salient features of typical examples may well be repeated here.

Externally the species is glossy, greyer than nitidum, more nearly equilateral than any of the other species, save personatum, with fairly prominent umbones; the nepionic shell is tolerably large, smooth, and frequently irridescent, and generally immediately followed by a series of concentric ridges as in nitidium, but much stronger.

Internally this form differs from all others in its hinge. The lateral teeth strike the eye at once as being somewhat longer, narrower, and less prominent than in most of the other species, while their apices are almost at the end furthest from the umbo. The paired laterals of the right valve are more equal in each pair in length than in other species, and stand out from each other and the shell margin. The cardinal teeth are flat-topped and practically parallel with the hinge line; the base of $c i i$ is continuous with aii and $c i v$ is mainly parallel with it; $c$ iii is only slightly curved. The essential arrangement of the cardinals, therefore, recalls that in subtruncatum.

Pisidium obtusalastrum, nom. nov., vice $P$. obtusale, C. Pfeiffer (of Jenyns non Pfeiffer) non Lamarck.

Jenyns (Trans. Camb. Phil. Soc., iv, 1832, p. 301, pl. xx, f. 1-3) identified his well-marked species with that described by C. Pfeiffer (Naturg. Deutsch. L.- u. Süssw.-Moll., i, 1821, p. 125, pl. v, f. 21, 22) who took the name from, whilst querying its identity with, the Cyclas obtusalis of Lamarck (Hist. Anim. s. Vert., v, 1818, p. 599).

There is no certainty as to the identification of either Lamarck's or Pfeiffer's shell, and neither adequately suggests Jenyns', consequently the name of Jenyns' shell has to be changed. 


\section{$2 \mathrm{BHL}$ Biodiversity Heritage Library}

1921. "Notes on some species of Pisidium." Proceedings of the Malacological Society of London 14, 209-220.

https://doi.org/10.1093/oxfordjournals.mollus.a063753.

View This Item Online: https://www.biodiversitylibrary.org/item/95719

DOI: https://doi.org/10.1093/oxfordjournals.mollus.a063753

Permalink: https://www.biodiversitylibrary.org/partpdf/69323

\section{Holding Institution}

Smithsonian Libraries

\section{Sponsored by}

Smithsonian

\section{Copyright \& Reuse}

Copyright Status: Public domain. The BHL considers that this work is no longer under copyright protection.

This document was created from content at the Biodiversity Heritage Library, the world's largest open access digital library for biodiversity literature and archives. Visit BHL at https://www.biodiversitylibrary.org. 